\title{
A bankvezetési kultúra változása a gazdasági válság hatására
}

\author{
L. KovÁCS
}

Absztrakt. A 2008/11-es globális gazdasági válság eredetét az elemzők jellemzően az amerikai másodrendű jelzálogpiaci válságra vezetik vissza. A gazdasági válság bizalmi válságba ment át, mely időben elhúzódást, hatásában pedig mélyülést jelentett. Összesített hatásként a pénzügyi szektor a valaha volt legmélyebb válságát élte át, melynek következményeként a tradicionális hatalmi viszonyok is megváltoztak. Hosszú idő után a bankok szabályozásáért és felügyeletéért felelős politikai vezetők globálisan vissza tudták venni a primátusi hatalmat a pénzügyi/gazdasági vezetőktől. A primátusi szerep elvesztése, a válság kitörésében játszott szerep, a társadalmi felelősség, a bankmentő akciók következményei, a reputáció csökkenése, a bizalomhiány mind közrejátszottak abban, hogy a bankvezetők és a banktulajdonosok új vezetési és gazdálkodási kihívásokkal találják magukat szemben. A tanulmány erre a nemzetközi és hazai kihíváshalmazra keresi a kulturális válaszokat.

JEL kód: B10, B30, G1

A bankárok életét, tevékenységét, kapcsolati hálóját hagyományosan egyfajta miszticizmus övezi. A valóságot a különböző okokkal magyarázható előítéletek széles tárháza (lásd: Kovács-Terták, 3. fejezet, 2016) torzítja. Így az irigyelt elismeréstől, a nélkülözhetetlenségen át, a vad gyülöletig terjed a bankárok megítélése. A gondolkodó embertől elvárható az, hogy helyén tudja kezelni a tényeket és felelősen fogalmazzon meg ítéleteket. A Szegedi húsvágók és sertéshizlalók egykori zászlószalagján egy Kölcsey idézet áll: „Minden pálya dicső, ha belőle hazádra derül fény!” A bankszektorban dolgozó tulajdonosok, felső- és középvezetők, munkatársak szerepe és felelőssége ebből a szemszögből is vizsgálható. Ugyanis a gazdasági válság egyes országokban tapasztalt elhúzódása és elmélyülése, amely mögé húzódva mások az emberi tudatlanságra és agresszivitásra alapozva érdekvezérelt folyamatokat építenek, minden felelős vezetőt óvatosságra kell, hogy intsen.

\section{A banki működés lélektana}

A ciklikusság egy természetes és jól ismert, bár időnként figyelmen kívül hagyott, alapvető gazdasági jelenség. A prociklikus tulajdonság az, ami a ciklikus ingadozásokat növeli. Így konjunkturális időszakban megjelennek az új befektetők, új pénzt visznek a piacra, mellyel tovább fütik a gazdaságot. Abban az esetben viszont, amikor a piac bizonytalanságokkal és recessziós félelmekkel válik terheltté, a nemrég érkezett befektetők kimenekítik a pénzüket, így voltaképpen megpróbálják a veszteségüket elkerülni, vagy legalábbis minimalizálni. Ez a természetes pénzügypiaci működés határozza meg a hitelkínálatot és az értékpapírpiaci keresletet is, és valójában ez adja a piac múködésének egyik 
természetes alapját. A hitelintézeti szektornak ezt a természetes működési sajátosságát kizárólag szabályozási és felügyeleti eszközökkel lehet csillapítani [14].

Ennek oka, hogy a bankszektor - mint a többi versengő üzleti szektor is - mindig kitölti a szabályozási keretét. A nemzetközi versenyhelyzet, a tulajdonosi nyereségelvárások és a hagyományos üzleti magatartás azt eredményezi, hogy az egyébként is innovatív és átjárható pénzügyi piacokon minden lehetőséget kihasználnak a szereplők. Ha az egyik szereplő ezt nem tenné, a másik azonnal a helyébe lépne.

Ezek a természetes tulajdonságok csak és kizárólag aktív szabályozással és hatékony kontrollal befolyásolhatók; ez a bizonyítottan működő módja a prociklikusság csökkentésének és a szolgáltatási meder szélessége szabályozásának. Éppen emiatt hozták egykoron létre maguk a kereskedelmi bankok az első jegybankokat, és ezért maradt a bankszektor a mai napig az egyik legszabályozottabb ágazat.

A 2008-as gazdasági válságot megelőző tartós gazdasági fellendülés éveiben a szabályozó és felügyelő hatóságok a szektor jó teljesítményétől elragadtatva elfeledkeztek a feladatukról, és gyakorlatilag tétlenül nézték a ciklikusan megérkező, mára már jól ismert turbulens események kibontakozását. Ezekről a természetes működési tulajdonságokról a 2008. előtti időszakban egyszerűen elfeledkeztek a hitelintézeti szektor működéséért felelős felügyeleti és szabályozó hatóságok. A válság kitörésekor és rendkívül gyors szétterjedésekor a felelősség vonatkozásában természetes emberi reakcióként - a saját hibáik legkisebb mértékű elismerése helyett - egyből a bűnbaknak kikiáltott pénzügyi szektorra kezdtek mutogatni, később pedig megkésett pótreakciókba kezdtek a szükséges intézkedéseken is túl.

A szabályozó hatóságok a 2008-as pénzügyi válságra - globális, európai és hazai szinten egyaránt - a prudenciális és egyéb szabályozási követelmények erőteljes szigorításával, egyfajta „szabályozási dömping”-gel, „szabályozási cunami”-val reagáltak. Az egyes államok az adófizetők pénzéből sok-sok euró és dollár milliárdot fordítottak a bajba jutott bankok kimentésére és a bankpánikok elkerülésére. Ennek fényében nem meglepő, hogy a politikai vezetők, valamint a politikusi szándékokat végső soron végrehajtó nemzetközi szabályozói testületek minden lehetséges szabályozói eszközzel megpróbálták megakadályozni a válság megismétlődését [2]. Azonban nem lenne szabad megfeledkeznünk a szabályozási és felügyelési hiányosságoknak a válság kitörésében és elmélyülésében játszott szerepéről sem. Az ezen szervezetek részéről megnyilvánuló túlszabályozás, és annak rendkívül aktív volta megpróbálta elhalványítani a korábbi felelősségeiket.

Ennek a túlszabályozásnak egyértelmű következménye az EU és tagországainak fokozott ütemben romló versenyképessége. Következményként az EU-s országok súlya tovább csökken a világgazdaságban. Az így kialakított mesterséges múködési környezet mellett tovább nehezítik a bankszektor működési feltételeit a politikai bizonytalanságok és a válságra hivatkozó, a már korábban is említett okok miatt elégedetlen szavazókból legitimitást merítő politikai erők megerősödése.

\section{A társadalmi felelősség kérdései}

A bankszektor és a gazdaság kölcsönös egymásra utaltságban működik, egyik sem lehet sikeres a másik sikere nélkül, és mindegyik sikertelen lesz a másik sikertelensége esetén. Ez az egymásra 
utaltság azonban nem áll meg a gazdaság, mint jogi személyiségek összessége külső határain, hanem áthatja az egész közeget is. A társadalmi stabilitás az organikus fejlődés alapja, a társadalmi változások pedig - történelmi tapasztalatok szerint - a gazdasági és politikai berendezkedés legfőbb lehetőség- és veszélyforrásai. Éppen ezért szükséges a társadalmi kérdések és elvárások folyamatos figyelemmel kísérése.

A mai világban a társadalmi információkhoz a felsővezetők csak szűrökön keresztül jutnak hozzá. Az emberi mélységben is valós információkat a történelmi társadalmi szervezetek, így pl. az egyházak tudják megbízhatóan közvetíteni. Ezért most egy ilyenre hagyatkozunk. Az Európai Protestáns Egyházak Közössége [4] firenzei nagygyúlése 2012-ben Nyilatkozatot fogadott el, mely válasz volt a gazdasági válság kérdéseire.

Nézzük megközelítését: „A mostani válság következményeként sok ember fél a jövőtől. Sokakat érint Európában a munkanélküliség, a csökkenő jövedelemszint, a jóléti szolgáltatások visszafogása és a megszorító intézkedések, melyek hatással vannak a közszolgáltatások finanszírozására és a növekvő szegénységre. Az egyik legaggasztóbb folyamat a fiatalok munkanélküliségének különösen magas aránya, amely sok országra jellemző. A mélyen gyökerező egzisztenciális aggodalom és a jövőbeli kilátások teljes hiánya miatt tömegek vonulnak az utcára.

A CPCE, 2012 Nagygyűlése tisztában van azzal, hogy ezekre a problémákra nincsenek egyszerű válaszok, nincs egyetlen gyógymód, melyet alkalmazni lehetne, főként úgy, hogy Európa gazdasága és pénzügyi piaca ennyire szoros kapcsolatban áll a globális gazdasági és piaci szereplőkkel. ..... Mind a saját országainkban, mind az egész világon a szegények és a gazdagok közötti szakadék egyre nő. A válság nem csak Európában, de az egész világon szedi áldozatait. Minden a helyzet megoldására tett javaslatot alaposan mérlegelni kell a tekintetben, hogy milyen hatékonyan segítik a leginkább érintett embereket és társadalmakat, milyen lehetséges hatással bírnak az európai integráció stabilitására, és mennyiben járulnak hozzá a globális szolidaritás előmozdításához." [4]

A Nyilatkozat több igen jelentős állásfoglalást is tartalmazott:

- Bátorság az igazsággal való szembenézéshez. Ebben megkérdőjelezi „,azt a kizárólagos igénnyel hangoztatott álláspontot, amely szerint az aktuális politikai stratégia az egyetlen megoldás a válságra... A válság nem oldódik meg egyik napról a másikra. Az aktuális válsággal való szembenézésnek az a legfőbb célkitűzése, hogy teret nyisson a nagyobb fokú igazságosságra, szolidaritásra és összhangra épülő társadalom létrehozását célzó kreatív cselekvéshez." [4]

- A demokrácia megerősítése. Ezt az alábbiakkal is indokolja: „Az emberek egyre inkább úgy érzik, hogy távoli erőközpontok döntéseinek vannak kiszolgáltatva. Ez a fejlemény nem végső soron annak köszönhető, hogy a politikai döntéshozatal az elmúlt években növekvő mértékben liberalizálta a pénzügyi szektort, és a nyilvános kontrol korábbi formáit lebontotta. A Nagygyülés meg van győződve arról, hogy a válságot csak úgy lehet hatékonyan és hosszú távon is fenntarthatóan legyőzni, ha az államok Európa szerte minden szinten megerősítik az átláthatóbb és demokratikusabb folyamatokat." [4]

- A társadalmat befolyásoló következmények figyelembevétele. Itt a döntések társadalmi hatásainak rendszeres és átfogó elemzését hangsúlyozza, mivel: „az EU európai szintű gazdasági kormányzásának aktuális megfogalmazásában, amely az elmúlt két évben túlzott hangsúlyt 
fektetett a megtakarításokra és költségvetési konszolidációra, a társadalompolitikai célok tényleges mérlegelése nélkül”. [4]

- Igazságos adópolitika „Általánosságban túl kevés figyelem hárul a fiskális politikai megoldásokra a megszorításokhoz képest, a költségvetési konszolidációra szolgáló eszközök mérlegelésekor. ... hatékony és szigorú intézkedések szükségesek az adókerülés és adócsalás felderítésére és leküzdésére, és meg kell erősíteni, illetve ki kell bővíteni az adóhatóságok müködését." [4]

- Pénzpiacok szabályozása. „Magától értetődő, hogy a bankokat és pénzügyi piacokat érintő tervezett szabályozás kulcsfontosságú, nem csak az Európai Unió, de az egész kontinens jövője szempontjából. ... A pénzügyi és banki szektor folyamatos ellenőrzést, etikailag megalapozott szabályozást igényel, hatékony és jól érvényesíthető eszközökkel." [4]

- „Nem” az újjáéledő nacionalizmusra. Ebben felhívják a figyelmet arra, hogy az általános bizalmatlanság a populizmus táptalajává válik.

- Gazdasági modellek újragondolása. Mely arról, szól, hogy a gazdasági növekedés mindenek fölé helyezése helyett a javak új igazságosabb elosztására, a biztonságos foglalkoztatásra, a stabil szociális rendszerekre, a jó közszolgáltatásokra és végső soron a fenntartható gazdaságra, a Föld (a teremtett világ) megőrzésére kell helyezni a hangsúlyt.

- Felszólítás az európai szolidaritásra. Ebben a béke, a szabadság és az igazságos jólét előremozdítása a szolidaritás célja, és felhívja a figyelmet az éghajlatváltozás, a demográfiai változások, a világgazdaság és a politikai átalakulások veszélyeire, melyek természetesen túl mutatnak Európa határain.

Az európai társadalmi kihívások független, bibliai alapon nyugvó megismerése után szeretnénk kitérni a nemzetközi bankszektor helyzetére.

\section{Bizalomhiány a pénzügyi szektorban}

„Semmi kétség afelől, hogy a bankárok és az egész ipar az egyik valaha is történt legrosszabb bizalmi válságot élik át. A 2008-as és 2009-es felfordulás fő szerepet játszott az közbizalom elvesztésében, de a probléma nem ért véget a válság legakutabb fázisával. Még most, hét évvel később is nagyon gyenge a bankszektorba fektetett bizalom. ...De a bizalmatlanság nem korlátozódik magukra a bankokra. Mind a befektetők, mind az ügyfelek kevésbé bíznak a bankszektor korrekt múködésében és abban, hogy a felügyelők és szabályozók képesek megelőzni a túlzott kockázatvállalást.” [10]

A bankszektorban a bizalomhiány nagyon sok mindent ellehetetlenít, ugyanis a banki szolgáltatások a kölcsönös bizalomra épülnek. Betétet csak a megbízható intézményekre bíznak a felelős megtakarítók, hitelt csak a megbízható adósoknak adnak a bankok, továbbá a számlavezetés, a pénzátutalás, stb. szintén az intézményi bizalmon alapulnak.

Európa gyors gazdasági fejlődése az ipari forradalommal indult el; a hitelintézeti szektor ekkorra vált képessé olyan mértékű tőkekoncentrációra, mely az iparosítást, a gyárak alapítását lehetővé tette. Azóta minden típusú piacgazdaságban a bankszektor a gazdasági fejlődés mozgatórugójaként és munkahelyteremtőként jelenik meg. [8] Azaz a bankszektor a szükséges és jogos bizalom visszaszerzése nélkül nem tudja alap funkcióit megfelelően betölteni, ami pedig visszafogja az általános gazdasági fejlődést. Azaz a bizalom helyreállítása nem csak a bankszektornak, hanem a 
hasonlóan bizalmatlansággal sújtott felügyeleti és szabályozó hatóságoknak, továbbá a kormányoknak is alapvető érdekük.

Ennek a folyamatnak része a banki szabályozási és felügyeleti reform. Ez érintette a tőke- és likviditás szabályozást, a kockázatok kezelésének és menedzselésének kérdéseit, a vezetői felelősséget és ösztönzéseket, a stressz teszteket és az ezzel kapcsolatos elvárásokat. A felügyeletek - részben elfedve a korábbi hiányosságokat és lazaságokat - a korábbinál sokkal alaposabbak, szigorúbbak lettek. Ennek a társadalom számára is érzékelhető eleme a fogyasztóvédelem megerősítése.

\section{A bankszektor feladata a bizalom helyreállításában}

A bankszektor feladta a bizalom helyreállításában: „A bankoknak ismét az alapfunkcióikra kellene hangsúlyt fektetniük, azaz:

- értékes befektetési lehetőségeket biztosítani a megtakarítók számára, védettséget biztosítva a likviditási kockázatoktól, valamint

- forrásokat biztosítani azoknak, akiknek szükségük van rá és eközben értékelni, nyomon követni hitelképességüket.

... Másodszor, a bank vezetősége illetve elnöksége felelősségtudattal kell, hogy tartozzon a bank egyéni kockázati kultúrájának fejlesztéséért, hogy ezáltal, a bank a hosszútávú üzleti perspektíva szem előtt tartásával tudja kezelni a kockázatokat, s az átláthatóságot és a felelősségre vonhatóságot támogassa.

Minden banknak szüksége van egy erős kulturális alapra: ez testesíti meg a bank lényegét, törekvéseit és magában foglalja, hogy egy profit-orientált szervezetről van szó. ...

- Ez az erős kulturális alap közös értékrendként kell, hogy szolgáljon az egész szervezeten belül.

- Ezekre az alapokra építve, minden banknak kell, hogy legyen egy egyértelmű kockázati politikája, amely segíti őt üzleti céljainak elérésében. Ugyanakkor ennek a politikának biztosítania kell azt, hogy az intézmény azon kockázatvállalási tevékenységei, melyek meghaladják kockázati étvágyát, felismerhetőek és időben intézhetőek legyenek.

- Ezt ki kell, hogy egészítsék azok az egyértelmű irányítást meghatározó folyamatok és kötelezettségek, amelyek a döntéshozáshoz, kockázatkezeléshez és auditáláshoz szükségesek.

- Végül, egy banknak szüksége van olyan jól múködő kommunikációs mechanizmusokra és informatikai rendszerekre, amelyek összekötik döntéshozó, kockázatkezelési és ellenőrző szerveit, hogy így az információ eljuthasson oda ahol szükség van rá, valamint hogy a bank céljai, politikája és értékei átláthatóak legyenek és tudatosuljanak intézményen belül.

Harmadszor, a bankok felsővezetői és igazgatóságai megfelelő ösztönző módszereket kell, hogy kialakítsanak szervezeteiken belül ... a hosszútávú perspektívák elősegítéséhez. ... A legfontosabb, hogy az emberek elhiggyék, hogy a vezetők valóban felelnek beosztottjaik magatartásáért." [10]

A végső tulajdonosokról külön szót kell ejteni, különösen az olyan országok esetében, ahol a külföldi/távoli tulajdonosok a bankszektor meghatározó tulajdonosai. Ilyen esetben a leánybank tevékenységét a központi, tulajdonosi elvárásoknak való maradéktalan megfelelés hatja át. A versenyben túlpörgő profit elvárások, ezekbe illeszkedett közép-európában a devizahitelek gyors és nagymértékű elterjedése, rendszerszintű pénzügyi kockázatot hoztak a térségbe, amely végül a bizalmi 
faktor drasztikus csökkenését eredményezte. A távoli tulajdonosoknak is el kell fogadniuk, hogy a globalizált gazdasági és politikai környezetben a bankszektorral szembeni elvárások, felelősségi kérdések jelentősen nem térhetnek el az anyabank és a (távoli) leánybankok esetében.

A felsorolt változások és feladatok sok-sok munkával, fáradtsággal, a profit egy részéről való lemondással, azaz jelentős költséggel is járnak.

\section{Egyes devizahiteles tények Magyarországon}

A gazdasági válság felkészületlenül érte a magyar gazdaságot és a pénzügyi rendszert. Ennek egyik nemzetközi következménye volt a stabil tartalék valuta, a svájci frank felértékelődése és a forint jelentős értékvesztése. A számok nyelvére lefordítva pl. a svájci frank árfolyama 2008. szeptember 1. és december 31. között 147,82-ről 177,78 HUF/CHF-re nőtt. Ez a deviza, elsősorban a svájci frank alapú jelzáloghitelek volumene alapján a magyar társadalom egy jelentős részének a havi hiteltörlesztésben az árfolyamváltozással arányos növekedést hozott.

A válságot megelőző években a magyar forint a korábbi alulértékeltség miatt, az inflációs különbség ellenére, erősödni tudott. Ez az átmeneti erősödés sokakat, köztük szakembereket is megtévesztett. Így azt a téves képzetet eredményezte, hogy a deviza hitelesek tartósan csak jobban járhatnak, mint a forint hitelesek. A forint gyengülés és ennek hatása negatív meglepetésként érte a társadalmat, mely feszültség különböző okok miatt még tovább gerjedt, és a devizahitelezéssel kapcsolatban téves eszmék terjedését okozta. Ezek közül négy valótlan állítást egy korábbi tanulmányban már megvizsgáltunk [6]:

- A devizaalapú hitel sohasem látott devizát. (Volt-e deviza forrásként a devizaalapú hitel mögött?)

- A bankok az árfolyamkockázatot ügyfeleikre hárították, és nem tájékoztattak az árfolyamkockázat valóságos mértékéről.

- A devizaárfolyam romlásából a bankok nyereségre tesznek szert.

- Az árfolyamrés (eladási és vételi árfolyam) alkalmazása tisztességtelen, illetve az árfolyamrés feltüntetésének a hiánya miatt semmis a devizaalapú hitelszerződés.

A tanulmányban ezek a téves állítások tételesen megcáfolásra kerültek. Habár komoly pénzügyi szakemberek ezeket sohasem állították, a populáris média és egyes önjelölt közgazdászok/jogászok ezeket mégis hatékonyan terjesztették.

Most e tanulmányban csak és kizárólag az árfolyam és a devizahitelezés kapcsolatának a hátterével fogunk foglalkozni.

A bankszektor egyik alap szolgáltatása az, hogy egy jövőbeli időpontra nézve előre, meghatározott árfolyamon más devizát biztosítson. Ilyenre van szüksége pl. azon export vállalatoknak, akiknek a vevőjük időben később fizet, amennyiben az exportálók a későbbi időpont miatt az árfolyamváltozás kockázatát el akarják kerülni. 
A bankszektor a jövőbeli árfolyamjegyzést mindenki számára nyitott és elérhető szolgáltatásként nyújtja. A jövőbeli árfolyam meghatározási metódust egy 2007-es, kerekítéseket tartalmazó, számpélda alapján mutatjuk be.

$\mathrm{Az}$ 1.000.000,- HUF betétként 8\%-os HUF bankközi kamat mellett egy év múlva 1.080.000 Ft-ot fog érni.

Amennyiben a mai árfolyam $160 \mathrm{HUF} / \mathrm{CHF}$, akkor az 1.000.000,- HUF-ért ma 1.000.000/160 = 62.500,CHF-et lehet kapni. Ennyi CHF betét 2\%-os CHF bankközi kamat mellett egy év múlva 63.750,- CHF-et fog érni.

A bank szempontjából indifferens (különben a pénzügyi piacokon azonnal arbitrálnák a bankot és ezzel jelentős veszteséget szenvedne el), hogy a pénz milyen devizanemben kamatozik. Ezért a jövőbeli, egy év múlvára meghatározandó árfolyam a jövőbeli értékek hányadosa: 1.080.000/63.750 = 169 HUF/CHF lesz. Azaz a jövőbeli árfolyam, melyen az ügyfelek számára deviza adható/vehető minden esetben a kamathozamok pontos hányadosa: $160 *(1,08 / 1,02)=169$.

Durva közelítésben az inflációs különbség miatt várható árfolyamok és a jövőben esedékes piaci árfolyamok (amennyiben az érintett nemzetgazdaságok fejlődésben nincs valamilyen irányú sokkhatás) hosszú távon azonos görbére esnek. Ez pedig jó alapot nyújt arra, hogy megvizsgáljuk a hosszú távú eladósodás esetén várható törlesztési karakterisztikákat.

Az egyik eset az, hogy a hitelek nyújtása relatíve magas (10-15\%-os) kamaton történik, ahogy ez a gazdasági válság előtt Magyarországon forintban történhetett. Ilyen esetben, az első időszakban a hitel felvevőknek igen magas törlesztőrészlettel kell számolniuk, akár a hitel összegének 20\%-át is vissza kell fizetniük az első évben. Aztán az évek múlásával - a bérjövedelmek növekedése és az infláció miatt - a törlesztési teher aránya a bérből jelentősen csökken, majd a futamidő végére nevetségesen alacsonnyá válik.

A másik eset az, hogy a hitelek nyújtása relatíve alacsony (2-5\%-os) kamaton történik, amint ezt a svájci frank alap biztosította. Ekkor azzal kell számolni, hogy az inflációs (értsd: kb. kamat) különbség miatt ez az alacsony kamatozású deviza folyamatosan fel fog értékelődni, és ezzel folyamatosan nőni fog a havi törlesztőrészlet. Azonban amennyiben a bérnövekedés megfelel az inflációs különbségnek, akkor a havi törlesztőrészlet a havi rendszeres bérjövedelemnek változatlan részét fogja elvinni. Azaz ebben az esetben a havi törlesztőrészlet terhelése változatlan marad a hitel teljes futamideje alatt: az elején nem lesz nagyon nehéz, de a vége sem lesz nagyon könnyü. Olyan ez, mintha az aranyásó, minden hónapban átlagosan egy hetet dolgozna az otthonáért. Ideális körülmények mellett társadalmi szinten ez a kívánatos struktúra! 


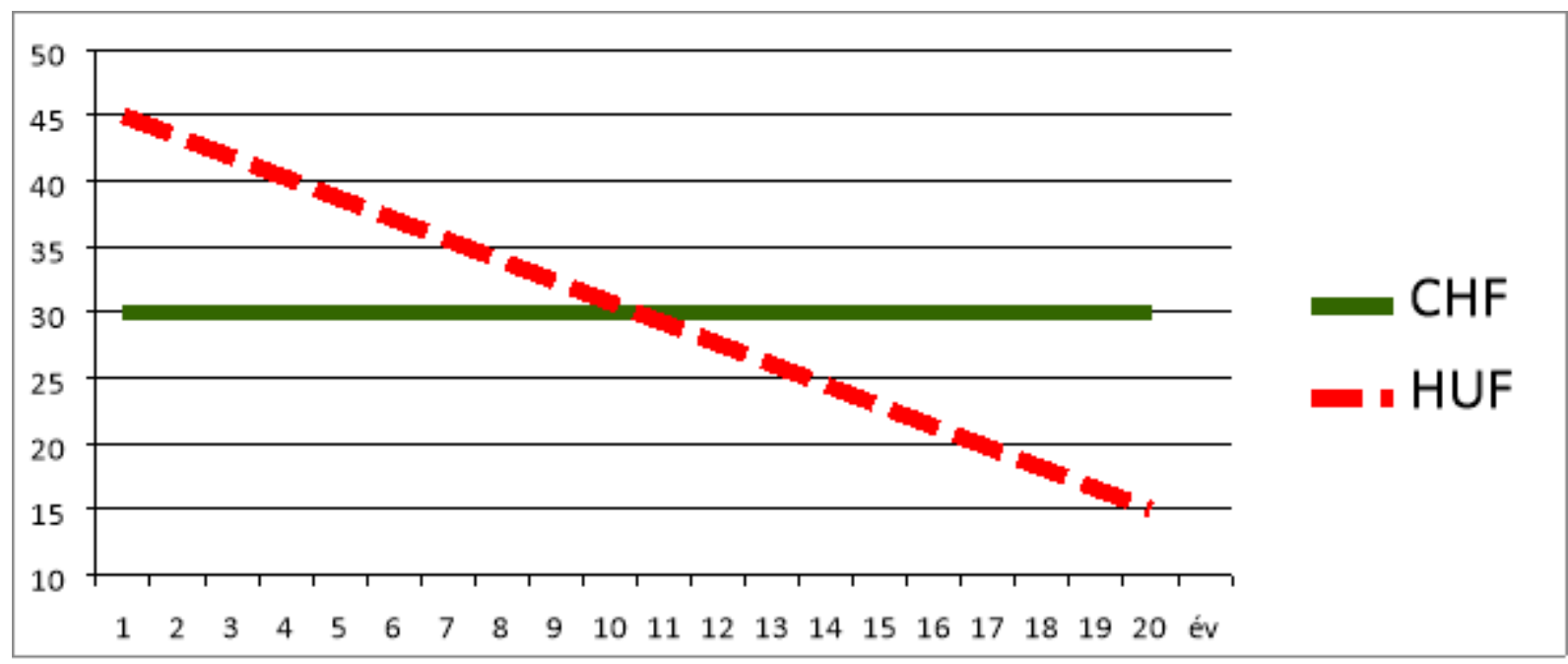

1. ábra: A lakáshitel törlesztés ideális, elméleti karakterisztikája

(Forrás: Saját szerkesztés)

Ahogy említettük, ez a hatás az árfolyamok és jövedelmek ideális, folyamatos és egyenletes változása esetén következik be. Évtizedes távlatokban érdemes lehet ezzel a karakterisztikával számolni. Nézzük meg ezt 2005-tól, a devizahitelezés tömeges elindulásától 2016-ig!

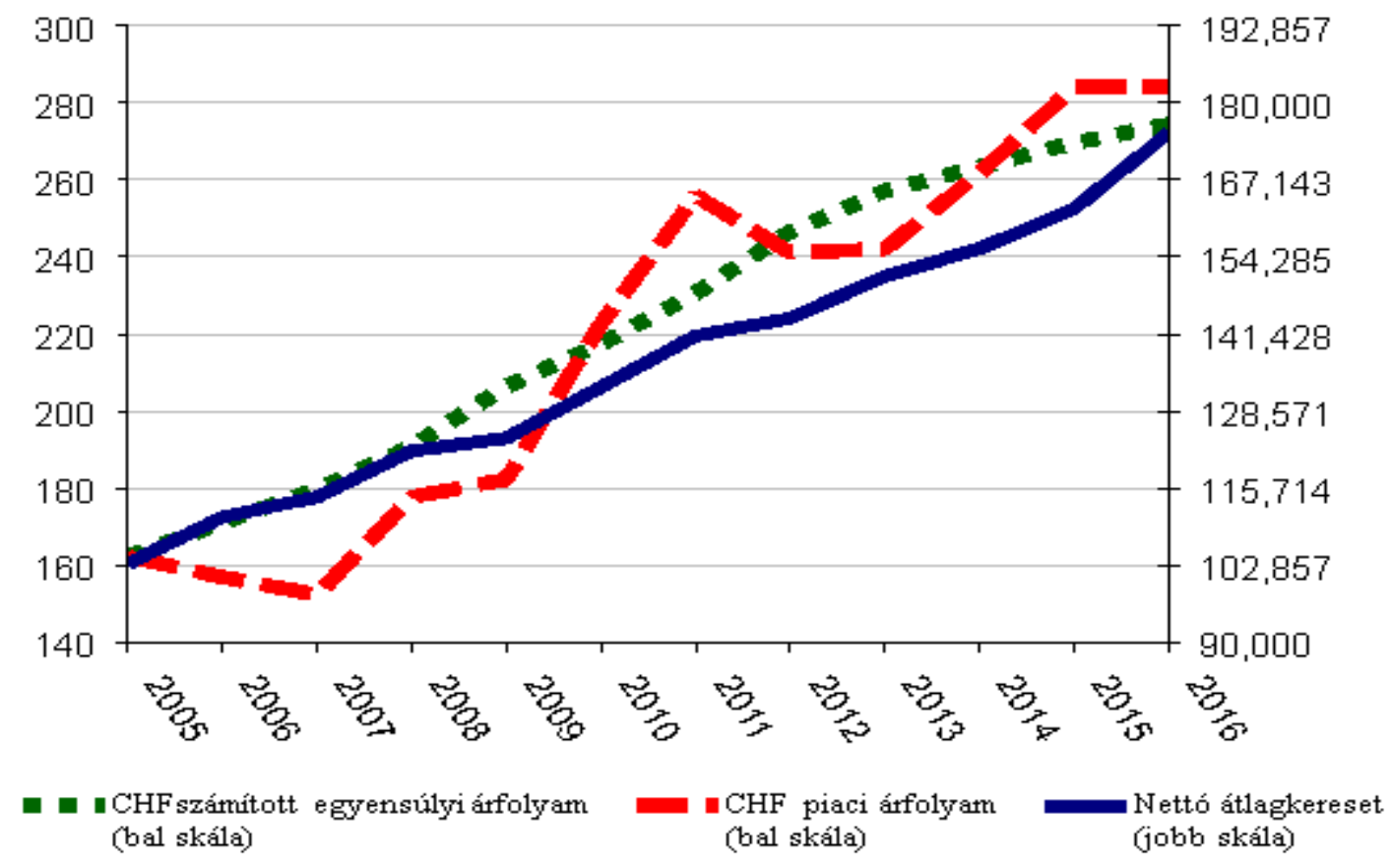

* Az árfolyam- és a bérskála azonos százalékos növekedés szerint skálázott!

2. ábra: A magyarországi nettó bérek, a várható és a piaci árfolyamok alakulása 2005-2016*

(Forrás: Saját összeállítás (KSH, MNB adatok alapján), ábra: Vass Péter) 
Ahogy látható, a gazdasági válság kitöréséig a bérek együtt haladtak a banki számolt árfolyammal, azonban a béremelkedés a gazdasági válsággal megtört, látható korrekció 2015-tól jelent meg. A piaci árfolyamok a banki számolt árfolyamtól először lemaradtak, majd fölé kerültek; a piaci árfolyam évtizedes trendje azonban a banki számolt árfolyamgörbére illeszkedik.

\section{A bankszektor terhei a válság során}

A tényeket bemutató számokat van aki érti, van aki szereti, de van aki nem tudja, vagy nem akarja megérteni, elfogadni. Ez így volt korábban is. A társadalmi hatások azonban szükségesé tették, hogy a bankszektor is súlyos részt vállaljon a devizahiteles kérdés rendezésében.

Ez a folyamat a sajtó élénk bevonódása mellett a közvélemény részletes tájékoztatásával történt meg. E tanulmányban azt érdemes kiemelni, hogy voltak olyan lépések, melyekben a kormány, a jegybank és a bankszövetség (a bankok képviseletében) aktívan együtt müködtek, s voltak olyanok melyek ellen a bankszövetség kategorikusan tiltakozott.

A Magyar Bankszövetség így támogatta és kezdeményezte az árfolyamgátat, majd a forintosítást, mely végül a jelzálog, a gépkocsi és a személyi hitelállomány teljes forintosítását eredményezte. A magyar bankszektor többszázezer hiteles és együttműködő ügyfél esetében alkalmazta az egyedi, ügyfélre szabott megoldásokat; úgy, mint pl. átütemezés, tőkemoratórium. A Bankszövetség aktívan vett részt a tömeges lebonyolításra alkalmas Nemzeti Eszközkezelő és az egyedi ügyfélkezelést igénylő családi csődvédelem kidolgozásában.

A bankszektorra helyezett egyes terhek ellen azonban azok igazságtalansága, befektetőket elbizonytalanító hatása, a kiszámíthatatlanság és negatív gazdasági/etikai vetületei miatt egyértelműen tiltakozott. Ide tartoznak az új típusú moratóriumok, továbbá a kedvezményes végtörlesztés, mely elsősorban nem a rászorultakon segített. Az ágazati különadók, melyek szerepet játszottak abban, hogy a magyar bankszektor elvesztette régiós versenyképességét és melyek azóta is visszavetik a gazdaság fejlődését [15]. A szövetkezeti típusú/eredetű intézmények miatti OBA feltöltések, miközben ezen intézmények konszolidációjára a kormány alapot különített el. A csaló brókerek miatt BEVA feltöltés, mely brókerek és intézményeik a bankszektortól elkülönítve, attól függetlenül végezték bűnös üzelmeiket. A tranzakciós adó és az ingyenes készpénz felvét, mely akadályozza a készpénzmentesítést és a gazdaság fehérítését. Az elszámoltatás, mely visszamenőlegesen írta felül a jogszabályok végrehajtását. Végül, igen hangsúlyosan, minden olyan nyilatkozat, utalás, okfejtés, demonstráció, stb., mely a kiszámíthatóságot, illetve a bankszektornak a normál gazdasági működéshez nélkülözhetetlen alapjaiba vetett bizalmat, valamint a fizetési fegyelem etikáját rombolta.

A bankszektor egyszeri és folyamatos (2014-2016.) terheit mutatják a következő ábrák: 


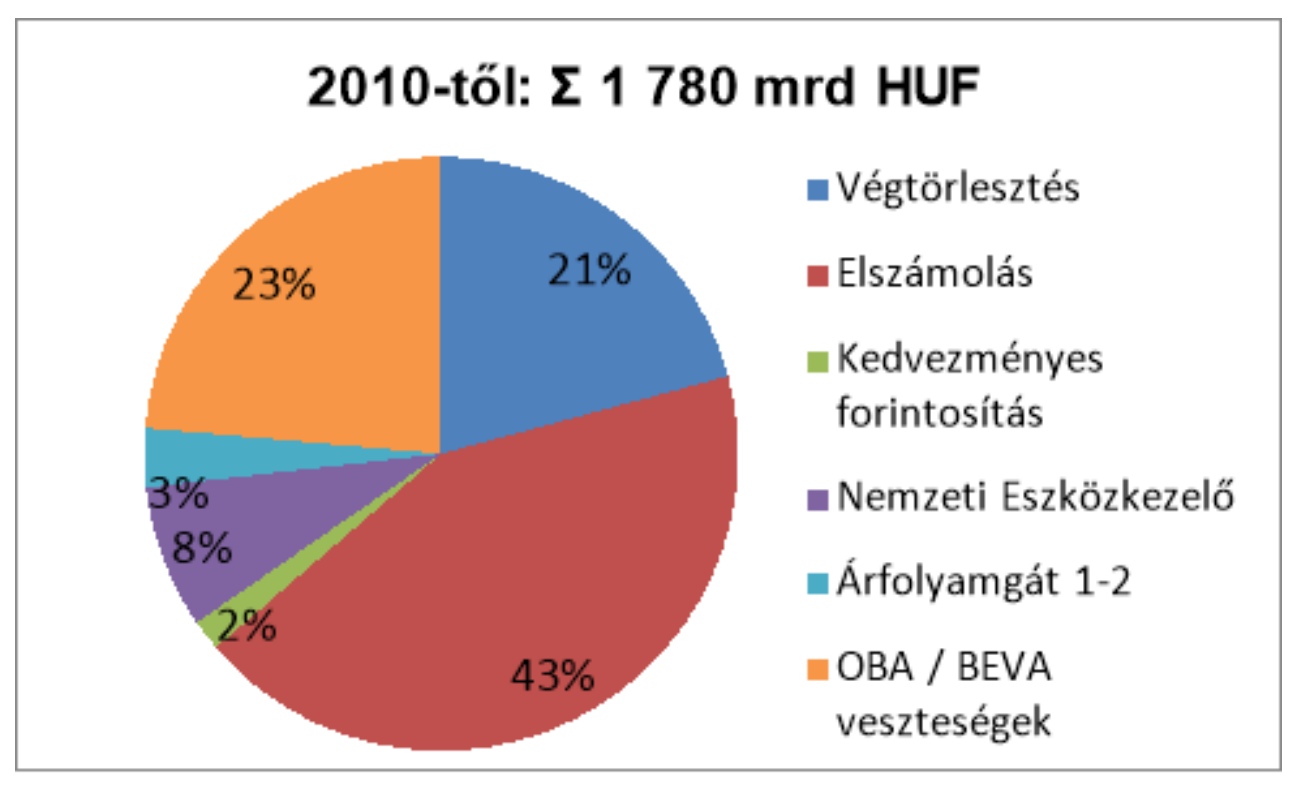

3/a ábra: A magyar bankszektor (egyszeri) válságterhelése

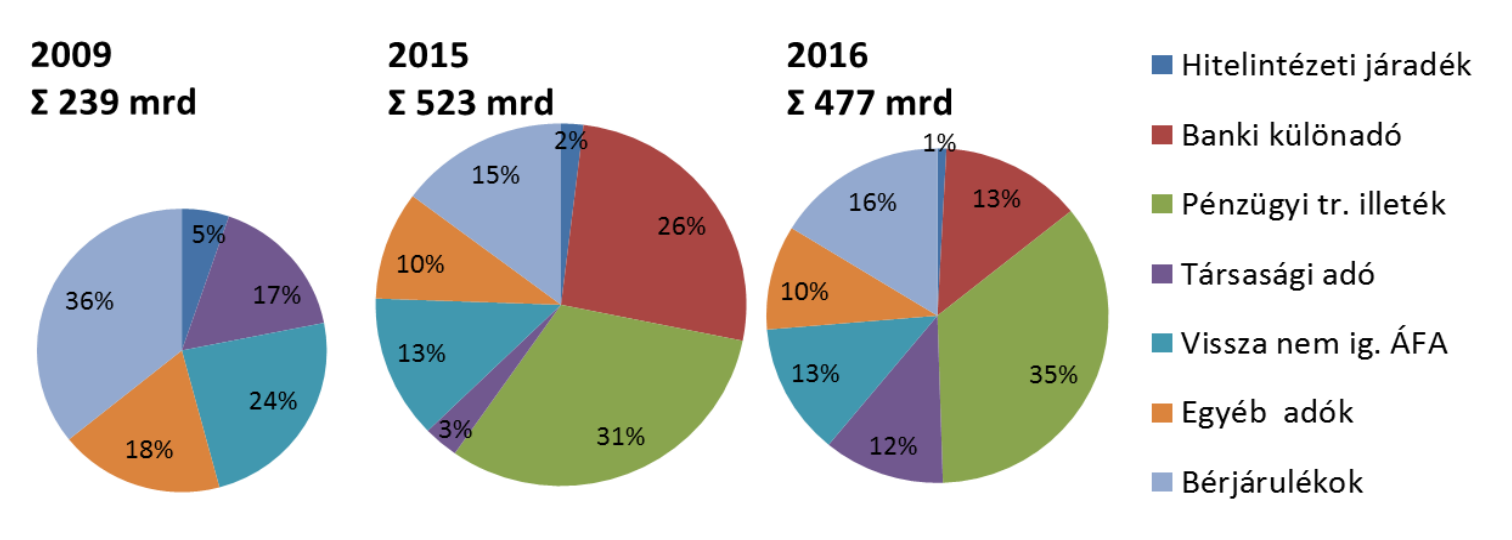

3/b ábra: A magyar bankszektor (folyamatos) adóterhelése

(Forrás: MBSZ adatok és becslések, ábra: Vass Péter)

\section{Új feladat: a bizalomhiány leküzdése}

A közismert magyar eseményekről térjünk vissza a nemzetközi feladatokra. A bankszektor válaszúthoz érkezett: Vagy tovább megy a válság előtti úton és tovább cipeli a bizalomhiány állapotát, vagy tudatosan és jelentős költséget is vállalva változtat rajta.

„A bizalom nélkülözhetetlen a bankszektor számára, nélküle a bankok nem működhetnek rendesen. Ez tehát, nem csak hátráltatja a gazdaságot, da magukat a bankokat is negatívan befolyásolja....

Másodszor, a bizalom hiánya negatívan befolyásolja a szabályozók és bankok viszonyát: ellenségesebbé válnak érintkezéseik. 
Harmadszor, a bizalom hiánya néhány bank, bankár felé, negatív érzéseket kelthet az egész ipar iránt, ez pedig negatív hatással lehet az üzletekre." [10]

Hozzáteszem: meg kell érteni a társadalom előítéletek által determinált hangját is. A pénzügyi kultúrával és tudással kapcsolatos kutatások és felmérések elképesztő eredményeket adtak. Erről tekintettel arra, hogy a konferencia a Pénz7 tematikus hetére esik - a következőkben külön is szólok.

A középiskolás diákok gyakorlatban alkalmazható tudásszintje alacsony. [9] „A felsőoktatás „nem garancia” a pénzügyi műveltségre. A felsőfokú végzettséggel rendelkezőknek csupán 49\%-a tudott helyesen válaszolni három egyszerű pénzügyi kérdésre.” [1, 13]. „Csupán minden negyedik család készít költségvetést, illetve tendenciaszerűen csökkent a kamatszámítással kapcsolatos pénzügyi feladatokat helyesen megoldani tudok arány is" [11] Az OECD 30 országra kiterjedő felmérése szerint Magyarország a 30. a rendszeres takarékoskodásban és a családi költségvetés megtervezésében [12]. Az előítéletek, köztük a bankellenesség egyik táptalaja a tudatlanság. „A pénzügyi ismeretek részleges vagy általános hiánya a nehézségek, válsághelyzetek jelentkezése esetén társadalmi elégedetlenséget, a pénzügyi intézményekkel kapcsolatos bűnbakkeresést és azok morális megítélésének zuhanását hozhatják magukkal. Az elmúlt években szinte minden európai országban láttunk ilyenre példákat sajtó cikkek, utcai megnyilvánulások, tüntetések és demonstrációk formájában." [7]

„A pénzügyi kultúra és tudás növelése tehát csökkenti a negatív előítéleteket, segíti a bizalom és a reputáció visszaállítását" [5], és mivel fokozza az együttműködések kiegyensúlyozottságát, segíti a természetes gazdasági folyamatok működését és ezek által a gazdasági fejlődést.

\section{Összefoglalás}

A tanulmány elején a gazdasági válság hatásaival kezdtük. Most a következményekhez érkeztünk el. Ahhoz, hogy a bankszektor és a vele szimbiózisban élő gazdaság tartós és kiszámítható fejlődését fogja vissza a kialakult bizalom hiány. A politikai vezetés, hosszú idő után visszavette irányítási primátusát a banki, gazdasági vezetőktől. Az irányítás megváltozásának, az elhúzódó és sokrétű válságkezelésnek, a tartós bizalomhiánynak az eredményeként a banki tulajdonosi, vezetői és munkatársi attitűdök jelentős változáson mentek keresztül. Ennek jelei egyre szélesebb körben érhetőek tetten, a teendők felrajzolódtak.

Bízunk abban, hogy a társadalom is felismeri, majd jutalmazóan el is ismeri a pozitív változásokat, melyek végső soron a gazdaság fejlődéséhez szükséges építőkövek.

\section{Hivatkozások}

[1] de Bassa Scheresberg, Carlo (2013) "Financial Literacy and Financial Behavior among Young Adults: Evidence and Implications," Numeracy: Vol. 6 : Iss. 2 , Article 5. DOI: http://dx.doi.org/10.5038/1936-4660.6.2.5. letölthető:: http://scholarcommons.usf.edu/numeracy/vol6/iss2/art5 
[2] Biedermann, Zsuzsánna - Orosz, Ágnes (2015): Eltérő irányú pénzügyi szabályozások a válság után? Az EU és az Egyesült Államok válaszainak összevetése. Hitelintézeti Szemle, 14. (1), pp. 30-56.

[3] Csányi, Sándor (2015): A magyar bankszektor kilátásai, előadás, MKT Vándorgyűlés, Miskolc, 2015. szeptember 3.

[4] CPCE (Európai Protestáns Egyházak Közössége) (2012): Szabadon a Jövőért. Felelősségvállalás Európáért, Firenzei nagygyűlés nyilatkozata, 2012. november 15., letölthető: http://www.reformatus.hu/mutat/szabadon-a-jovoert-felelossegvallalaseuropaert/

[5] Gortsos, Christos (2016): Financial Inclusion: An Overview of its Various Dimensions and the Initiatives to Enhance its Current Level, European Center of Economic and Financial Law, Working Paper Series No 2016/15, www.ecefil.eu

[6] Kovács, Levente (2013): A devizahitelek háttere, Hitelintézeti Szemle, 2013/3, pp. 183-193., ISSN 1588-6883

[7] Kovács, Levente (2015): A pénzügyi kultúra Európában, Magyarországon és a Miskolci Egyetemen, "Mérleg és Kihívások" IX: Nemzetközi Tudományos Konferencia „e"tanulmánykötet, Miskolci Egyetem, 2015. október 15. ISBN 978-963-358-098-1

[8] Kovács, Levente \& Terták, Elemér (2016): Financial Literacy, Kiadó: Verlag Dashöfer, Pozsony/Bratislava, p. 112. ISBN: 978-80-8178-016-5, letölthető: http://www.bankszovetseg.hu/hirek-aktualitasok/kovacs-tertak-financial-literacy-4018

[9] Kovács, Péter \& Révész, Balázs \& Ország, Gáborné (2014): A pénzügyi kultúra és attitűd mérése, "Marketing megújulás" konferencia tanulmánykötet, Szeged, 2014.08.272014.08.29. pp. 439-447. (ISBN:978-963-306-312-5)

[10] Lautenschläger, Sabina (2015): Reintegrating the banking sector into society: earning and reestablishing trust, 7th International Banking Conference, Milan, letölthető: https://www.ecb.europa.eu/press/key/date/2015/html/sp150928.en.html

[11] Németh, E. - Jakovác, K. - Mészáros, A. - Kollár, P. - Várpalotai, V. (2016): Pénzügyi kultúra fejlesztési programok felmérése, Kutatási jelentés, 2016. április letölthető: https://www.asz.hu/storage/files/files/Publikaciok/Elemzesek_tanulmanyok/2016/penzu gyi_kult_fejl_programok.pdf?ctid=976

[12] OECD (2016): International Survey of Adult Financial Literacy Competencies, letölthető: http://www.oecd.org/finance/oecd-infe-survey-adult-financial-literacy-competencies.htm

[13] Ország, Gáborné (2017): A hazai középiskolások pénzügyi kultúrájának vizsgálata, Ph.D. értekezés, Szegedi Tudományegyetem Közgazdaságtani Doktori Iskola

[14] Patai, Mihály (2015): A magyar bankrendszer régiós vetületben, Miskolci Egyetem „Mérleg és Kihívások" konferencia, 2015. október 15. 
International Journal of Engineering and Management Sciences (IJEMS) Vol. 2. (2017). No. 4.

DOI: 10.21791/IJEMS.2017.4.22.

[15] Siklós, Márta \& Mladonyiczki, Balázs (2016): A különadók szerepe az adózásban, Gazdaság és Pénzügy 2016/4. p. 273-304., ISSN 2415-8909

Továbbá a szerző itt nem feltüntetett saját írásai, tanulmányai az azokra való önhivatkozások nélkül! 